\title{
Florian Nowicki
}

Warszawa

\section{Teoria produkcji z Grundrisse i jej implikacje dla marksizmu}

Słowa kluczowe: marksizm, Grundrisse, produkcja, czas wolny, praca reprodukcyjna, inteligencja, klasa społeczna, klasa kulturowa, kapitalizm, komunizm

Z pewnych uwag poczynionych przez Karola Marksa w Grundrisse wyłania się mimochodem interesująca (a nawet: zaskakująca) teoria produkcji mogąca mieć daleko idące implikacje dla marksistowskiej teorii klas i sposobów produkcji. Zajmiemy się najpierw rekonstrukcją tej teorii, a następnie jej rozwinięciem i wspomnianymi implikacjami. Rekonstrukcja polegać będzie na eksplikacji trzech tez Marksa celowo „wyrwanych” z szerszego kontekstu. Nie będzie to zatem wierna interpretacja fragmentów Grundrisse, z których owe tezy zostały zaczerpnięte, ale ich świadoma nadinterpretacja - polegająca na przesadnym wyeksponowaniu myśli, które w tych fragmentach rzeczywiście się pojawiają, aczkolwiek nie jako - organizujące narrację - myśli przewodnie, ale raczej jako myśli marginalne (nienależące do tematu głównego, ale, jak sądzę, wiernie dokumentujące Marksowską aksjologię).

\section{Teza pierwsza: wszelka produkcja jest w istocie produkcją człowieka}

Pierwsza teza tej teorii głosiłaby, iż wszelka produkcja jest $w$ istocie produkcja człowieka, co oznacza, iż produkcja produktów (niebędacych ludźmi ani ich właściwościami) jest tylko „,przelotnym momentem” produkcji globalnej. Tezę tę przypisuję Marksowi na podstawie następującej wypowiedzi:

Gdy rozpatrujemy społeczeństwo burżuazyjne w jego całokształcie, to okazuje się, że ostatecznym rezultatem społecznego procesu produkcji jest zawsze samo 
społeczeństwo, to znaczy sam człowiek w jego więzi społecznej. Wszystko, co posiada uchwytny kształt, jak produkt itp., okazuje się tylko momentem, przelotnym momentem w tym ruchu. Nawet bezpośredni proces produkcji okazuje się tu tylko momentem. Same warunki i przedmiotowa treść procesu stanowią podobne momenty, a jako jego podmioty występują tylko indywidua, ale indywidua w stosunkach wzajemnych, które stosunki te i reprodukują, i stwarzają od nowa. Jest to ich własny, nieustanny proces ruchu, w którym indywidua odnawiają siebie samych, jak również tworzony przez siebie świat bogactwa ${ }^{1}$.

Jest to wypowiedź na pierwszy rzut oka banalna, a zasadniczą sprawą, na którą zdaje się wskazywać, jest okoliczność, iż wszelka produkcja jest reprodukcją określonych stosunków produkcji czy szerzej: określonego całokształtu stosunków społecznych, a istota człowieka jest właśnie, jak wiemy z Tez o Feuerbachu, „całokształtem stosunków społecznych"2. Czyli: produkując rzeczy, produkujemy - niepostrzeżenie - stosunki między ludźmi, a więc i aktualną , ,istotę człowieka”. Jeżeli jednak w jej świetle zastanowimy się nad problemem adekwatnej hierarchizacji procesów produkcyjnych w obrębie produkcji globalnej, konsekwencje, do jakich dojdziemy, okażą się dość niebanalne.

Na gruncie „Zwykłej” Marksowskiej teorii produkcji za produkcję w sensie ścisłym uznaje się wyłącznie tak zwaną produkcję materialną, czyli produkcję środków utrzymania (wraz z produkcją środków produkcji środków utrzymania). Natomiast bezpośrednia produkcja człowieka (konsumpcja środków utrzymania, praca reprodukcyjna, edukacja itd.), ujmowana (zwłaszcza w odniesieniu do realiów gospodarki kapitalistycznej) jako proces reprodukcji siły roboczej, stanowi - w świetle tej teorii produkcję zaledwie pomocniczą, wytwarzającą/odtwarzającą kluczowe przesłanki zasadniczego procesu produkcji. Celem produkcji, jej produktem „ostatecznym”, jest produkt niebędący człowiekiem ani jego właściwością: pozaludzki przedmiot posiadający wartość (wszystko jedno, czy tylko wartość użytkową - jak w produkcji nietowarowej, czy zarazem wartość użytkową i wartość wymienną - jak w produkcji kapitalistycznej). Człowiek jest natomiast zaledwie „półproduktem” produkcji zasadniczej, jej „,́rodkiem” czy też „czynnikiem” (a poniekąd „ubocznym rezultatem”). Jakkolwiek również bezpośrednia produkcja człowieka (jako nosiciela siły roboczej) jest procesem wartościotwórczym (skoro siła robocza ma wartość) - wartością „ostateczną" jest wartość rodząca się w toku produkcyjnej konsumpcji siły roboczej, czyli w procesie tak zwanej produkcji materialnej.

Sytuacja zmienia się diametralnie, gdy poważnie potraktujemy tezę, iż wszelka produkcja jest $\mathrm{w}$ istocie produkcją człowieka. Za zasadniczy proces produkcji globalnej uznamy wówczas bezpośrednią produkcję człowieka, natomiast proces

1 K. Marks, Zarys krytyki ekonomii politycznej, thum. Z.J. Wyrozembski, Warszawa 1986, s. 579.

2 K. Marks, Tezy o Feuerbachu, w: K. Marks, F. Engels, Dzieła, t. III, Warszawa 1975, s. 7. 
tak zwanej produkcji materialnej okaże się zaledwie procesem pomocniczym - jest to bowiem proces (zaledwie) pośredniej produkcji człowieka. Tak zwana produkcja materialna oraz reprodukcja siły roboczej zamieniają się zatem „miejscami”: proces zasadniczy okazuje się procesem pomocniczym, a proces pomocniczy - zasadniczym, przy czym pod znakiem zapytania staje tożsamość bezpośredniej produkcji człowieka jako procesu reprodukcji siły roboczej.

Punkt widzenia teorii „,zwykłej” wyraża adekwatnie „ducha” produkcji kapitalistycznej, na gruncie której człowiek jest tylko środkiem procesu akumulacji kapitału.

Dlatego pogląd starożytny, według którego człowiek, jakkolwiek byłby ograniczony pod względem narodowym, religijnym, politycznym, zawsze stanowi cel produkcji, wydaje się bardzo wzniosły w porównaniu ze światem współczesnym, w którym produkcja jawi się jako cel człowieka, a bogactwo - jako cel produkcji ${ }^{3}$.

Teoria „Zwykła” (w zastosowaniu do produkcji burżuazyjnej) jest prawdziwa w tym sensie, iż rozpatruje produkcję burżuazyjną w sposób uwzględniający obiektywny fakt podporządkowania (na jej gruncie) procesu produkcji człowieka procesowi produkcji rzeczy (czyli ostatecznie: procesowi rozszerzonej reprodukcji kapitału). Teoria produkcji z Grundrisse sugeruje tymczasem, iż cel produkcji burżuazyjnej jest celem fałszywym. Prawdziwym celem produkcji, o czym wiedzieli starożytni, jest zawsze człowiek. Dochodzimy tą drogą do idei prawdziwego sposobu produkcji (czyli interpretacji komunizmu jako prawdziwego sposobu produkcji). Każdy sposób produkcji produkuje przede wszystkim człowieka i w każdym sposobie produkcji człowiek stanowi jedyny istotny produkt produkcji, ale nie każdy sposób produkcji o tym „wie”, a więc nie każdy sposób produkcji stawia sobie za cel wysoką jakość produkowanych na jego gruncie - ludzi. Fałszywe sposoby produkcji obierają inne cele odwodzące je od efektywnej realizacji celu prawdziwego. Jedynie prawdziwy sposób produkcji nie stawia sobie żadnych innych celów, to znaczy traktuje człowieka jako swój produkt zasadniczy (jedyny istotny); jako swój cel. Tylko na gruncie prawdziwego sposobu produkcji proces produkcji rzeczy (jako proces pośredniej produkcji człowieka, czyli jako pomocniczy proces procesu bezpośredniej produkcji człowieka) jest ściśle podporządkowany procesowi bezpośredniej produkcji człowieka. Celem jest maksymalizacja produktu bezpośredniej produkcji człowieka (czyli: najpełniejszy rozwój człowieka), a cała reszta (ogół procesów pomocniczych) musi być temu celowi najściślej podporządkowana.

Gdy zatem Marks stwierdza, iż „ostatecznym rezultatem społecznego procesu produkcji” „społeczeństwa burżuazyjnego w jego całokształcie” jest „sam człowiek w jego więzi społecznej”, a „wszystko, co posiada uchwytny kształt”, jak ,produkt”, a nawet „bezpośredni proces produkcji”, jest tylko ,przelotnym momentem” „ruchu,

3 K. Marks, Zarys krytyki..., s. 381. 
w którym indywidua odnawiają siebie samych", to spogląda on na owo społeczeństwo z punktu widzenia antycypującego przyszły, prawdziwy (czyli komunistyczny) sposób produkcji. Krytyka fałszywego celu produkcji kapitalistycznej jest, wypada dodać, nie tylko krytyką (właściwego kapitalizmowi) podporządkowania procesu wytwarzania wartości użytkowej procesowi wytwarzania wartości wymiennej, ale zarazem „prewencyjną” krytyką takiego komunizmu czy socjalizmu, który by absolutyzował wartość użytkową, to znaczy podporządkowywał proces bezpośredniej produkcji człowieka procesowi wytwarzania wartości użytkowej, czyli procesowi pośredniej produkcji człowieka.

\section{Teza druga: rzeczywistym bogactwem są rozwinięte „sily ludzkie”, w szczególności: rozwinięte dyspozycje twórcze indywiduów}

$\mathrm{Z}$ tezy pierwszej (wszelka produkcja jest w istocie produkcją człowieka) wynika, iż rzeczywistym bogactwem jest bogactwo podmiotowe, czyli bogactwo tkwiące w ludziach, a nie rzeczach. Krytyka wartości wymiennej (jako celu produkcji) z perspektywy wartości użytkowej (jako alternatywnego celu produkcji) jest więc krytyką dalece niewystarczającą. Nie chodzi bowiem o to, by - po obaleniu panowania wartości wymiennej - ustanowić panowanie wartości użytkowej, ale o to, by obalić panowanie procesu wytwarzania bogactwa przedmiotowego nad procesem wytwarzania bogactwa podmiotowego.

Teza druga odpowiada na pytanie, czym jest owo bogactwo podmiotowe. Jest to oczywiście bogactwo osobowościowe: bogata indywidualność, wszechstronnie rozwinięta osobowość, zakładająca nieskrępowany „rozwój wszystkich sił ludzkich" jednostki, wśród których szczególną rolę odgrywają dyspozycje twórcze. Teza druga rekonstruowanej teorii produkcji brzmi zatem: rzeczywistym bogactwem sq rozwinięte „siły ludzkie”, w szczególności: rozwinięte dyspozycje twórcze jednostek. Tezę tę przypisuję Marksowi na podstawie następujących wypowiedzi:

Bowiem rzeczywistym bogactwem jest rozwinięta siła wytwórcza wszystkich indywiduów. Wówczas [VII-4] miarą bogactwa nie będzie już w żadnym razie czas pracy, lecz disposable time [rozporządzalny czas] $]^{4}$.

Czymże jednak jest in fact [faktycznie] bogactwo po zerwaniu zeń ograniczonej formy burżuazyjnej, jeśli nie stwarzaną w uniwersalnej wymianie uniwersalnością potrzeb, indywiduów, ich zdolności, rozkoszy, sił twórczych itp.? Jeśli nie pełnym rozwojem panowania człowieka nad siłami przyrody, zarówno przyrody w potocznym znaczeniu, jak i jego własnej natury? Absolutnym stymulowaniem jego skłonności twórczych, dla których nie ma innej przesłanki oprócz poprzedzającego rozwoju historycznego, czyniącego celem samym w sobie ów całokształt rozwoju, to znaczy rozwoju wszystkich sił ludzkich, jako takich, a nie mierzonych

4 Ibidem, s. 575. 
jakimiś z góry ustanowionymi strychulcami? Gdzie człowiek nie reprodukuje siebie jednostronnie, lecz stwarza swój całokształt? Gdzie nie usiłuje pozostać takim, jakim jest, lecz znajduje się w absolutnym ruchu stawania się? ${ }^{5}$

Jeżeli teza pierwsza „dowartościowuje” całą bezpośrednią produkcję człowieka (którą „zwykła” teoria produkcji „chowa” za pośrednią produkcją człowieka jako jej środek), to teza druga implikuje wyodrębnienie w ramach bezpośredniej produkcji człowieka dwóch ogniw: pomocniczego i zasadniczego. Ogniwem pomocniczym byłaby materialna reprodukcja ludzkiego życia (w szczególności: konsumpcja środków utrzymania i praca reprodukcyjna), zaś ogniwem zasadniczym, bezpośrednio wartościotwórczym: produkcja (bogatej) osobowości, w szczególności - stymulacja rozwoju dyspozycji twórczych.

Prawdziwym celem produkcji nie jest po prostu reprodukcja życia ludzkiego jako takiego, czyli - mówiąc kolokwialnie - byle jakiego życia ludzkiego, ale produkcja swoiście ludzkiego życia ludzkiego, czyli życia twórczego. Innymi słowy, materialna reprodukcja życia nie jest procesem wytwarzania bogactwa rzeczywistego, ale (zaledwie) produkcją materialnego substratu bogactwa rzeczywistego: by człowiek mógł się stawać podmiotem/produktem produkcji bogactwa rzeczywistego, musi zaspokajać swoje potrzeby materialne, musi żyć. Celem/bogactwem nie jest jednak życie, ale życie bogate, życie ludzi bogatych bogactwem swych osobowości (,sił ludzkich”), czyli w szczególności: bogactwem swych dyspozycji twórczych.

Teza druga sugeruje zarazem przeprowadzenie analogicznego rozróżnienia w odniesieniu do pośredniej produkcji człowieka, czyli do produkcji rzeczy. Produkowane przez człowieka rzeczy mogą być z jednej strony środkami utrzymania, czyli przedmiotami konsumowanymi w ramach pomocniczego ogniwa bezpośredniej produkcji człowieka, z drugiej zaś strony - środkami samorealizacji twórczej, czyli przedmiotami konsumowanymi w ramach zasadniczego (wartościotwórczego) ogniwa bezpośredniej produkcji człowieka.

W świetle tez pierwszej i drugiej proces produkcji globalnej (interpretowany jako proces, którego istotą/celem jest produkcja człowieka) rozpada się na cztery ogniwa:

\begin{tabular}{|l|l|l|l|}
\hline \multicolumn{2}{|c|}{ Pośrednia produkcja człowieka } & \multicolumn{2}{c|}{ Bezpośrednia produkcja człowieka } \\
\hline $\begin{array}{l}\text { 1. Produkcja środków } \\
\text { utrzymania (i środków } \\
\text { produkcji środków } \\
\text { utrzymania) }\end{array}$ & $\begin{array}{l}\text { 2. Produkcja środków } \\
\text { samorealizacji } \\
\text { twórczej }\end{array}$ & $\begin{array}{l}\text { 3. Materialna } \\
\text { reprodukcja } \\
\text { człowieka }\end{array}$ & $\begin{array}{l}\text { 4. Produkcja dyspozycji } \\
\text { twórczych człowieka, } \\
\text { czyli bezpośrednia } \\
\text { produkcja bogactwa } \\
\text { rzeczywistego }\end{array}$ \\
\hline
\end{tabular}

5 Ibidem, s. 381-382. 
Jedynie ogniwo nr 4 jest procesem bezpośrednio wartościotwórczym, czyli bezpośrednio produkcyjnym; ogniwa 1, 2 i 3 są natomiast tylko procesami pomocniczymi (,przelotnymi momentami” produkcji człowieka).

Jeżeli teza pierwsza jest polemiką z poglądem „współczesnym” (czyli burżuazyjnym), iż celem człowieka jest produkcja, przeciwko któremu przywoływany jest „pogląd starożytny”, iż celem produkcji jest człowiek, to teza druga jest już polemiką z „poglądem starożytnym”. Starożytni mieli bowiem na względzie człowieka „ograniczonego pod względem narodowym, religijnym, politycznym”, chcieli zatem reprodukować wyidealizowanego obywatela antycznego, gdy tymczasem Marksowi idzie o człowieka nieograniczonego, uniwersalnego, rozwijającego nieskrępowanie „wszystkie siły ludzkie”, przezwyciężającego własną twórczością wszelkiego rodzaju „ograniczoności”.

\section{Teza trzecia: produkcją dyspozycji twórczych (czyli bogactwa rzeczywistego) jest „wznioślejsza działalność” podejmowana w czasie wolnym}

Doszliśmy na razie do ogólnego pojęcia procesu produkcji dyspozycji twórczych człowieka jako jedynego procesu bezpośrednio wartościotwórczego, prawdziwie produkcyjnego. Teza trzecia odpowie nam na pytanie, jakiego rodzaju działalność jest ową produkcją.

Zaoszczędzenie czasu pracy jest równoznaczne z powiększeniem wolnego czasu, to znaczy czasu dla pełnego rozwoju indywiduum, które z kolei, jako największa siła wytwórcza, oddziaływa na siłę produkcyjną pracy. Z punktu widzenia bezpośredniego procesu produkcji można zaoszczędzanie czasu pracy uważać za produkcję kapitału trwatego; tym kapitałem trwałym being man himself [jest sam człowiek $]^{6}$.

Czas wolny - który jest zarówno czasem wolnym od zajęć, jak też czasem dla wznioślejszej działalności - przemienił oczywiście człowieka, który nim dysponuje, w inny podmiot i jako ten inny podmiot wstępuje on też teraz do bezpośredniego procesu produkcji. Bezpośredni proces produkcji to zarazem dla kształtującego się człowieka szkoła dyscypliny, podobnie jak dla człowieka już ukształtowanego, w którego głowie istnieje nagromadzona wiedza społeczeństwa, proces ten - to zastosowanie [zdobytej wiedzy], nauka eksperymentalna, nauka twórcza materialnie i wdrażana w praktykę 7 .

Teza trzecia brzmi zatem: produkcja dyspozycji twórczych (czyli bogactwa rzeczywistego) jest ,wznioślejsza działalność” podejmowana w czasie wolnym. Za „wznio-

6 Ibidem, s. 578.

7 Ibidem, s. 579 
ślejszą działalnością" kryć się może jedynie samorealizacja jednostki w dziedzinie twórczości artystycznej i naukowej wraz z kształceniem odpowiednich dyspozycji warsztatowych. „Bezpośredni proces produkcji”, przez który Marks rozumie tak zwaną produkcję materialną (czyli pośrednią produkcję człowieka), nie stwarza pola dla rozwijania dyspozycji twórczych. Owszem, jest on - dla jednostki - szkołą dyscypliny, a także okazją do stosowania wiedzy (zdobytej w czasie wolnym), ewentualnie również jej testowaniem („,nauką eksperymentalną”). Dyspozycje twórcze rozwijane są jednak w czasie wolnym od pracy. To czas wolny jest „,zasem dla pełnego rozwoju indywiduum”; to czas wolny (jako czas „wznioślejszej działalności”) przemienia „człowieka, który nim dysponuje, w inny podmiot”, czyli w człowieka bogatego, twórczego.

Tezę drugą podparliśmy między innymi następującą wypowiedzią Marksa: „Bowiem rzeczywistym bogactwem jest rozwinięta siła wytwórcza wszystkich indywiduów. Wówczas [VII-4] miarą bogactwa nie będzie już w żadnym razie czas pracy, lecz disposable time [rozporządzalny czas]". Omawiając tezę drugą, zignorowaliśmy jednak pojawiający się tu wątek czasu wolnego jako „miary” bogactwa. Obecnie, w kontekście tezy trzeciej wskazującej na rolę czasu wolnego jako „czasu dla pełnego rozwoju indywiduum”, możemy zastanowić się nad sensem tezy, iż „miarą” bogactwa będzie czas wolny. W świetle naszego przypuszczenia czas wolny stanie się „miarą" bogactwa dlatego, gdyż to w czasie wolnym podejmowana będzie „wznioślejsza działalność” stymulująca rozwój dyspozycji twórczych - a one właśnie są bogactwem rzeczywistym. Im więcej czasu wolnego, tym więcej „wznioślejszej działalności”, a więc tym większe bogactwo ludzkich dyspozycji twórczych, czyli bogactwo rzeczywiste. Czas wolny przemienia człowieka w inny podmiot, czyli w podmiot bogatszy.

Marks uporczywie podkreśla użyteczność tego rodzaju przemiany z punktu widzenia „interesów” procesu pośredniej produkcji człowieka, nazywając wręcz człowieka „kapitałem trwałym”, czyli degradując go niejako do roli środka produkcji. Rozwój człowieka - w czasie wolnym - wzmaga produkcyjną siłę pracy. Mogłoby to sugerować, iż czas wolny będzie „miarą" bogactwa właśnie z uwagi na wpływ (rozwiniętych w czasie wolnym) dyspozycji twórczych robotników na siłę produkcyjną pracy. Bogactwem rzeczywistym byłaby wówczas siła wytwórcza jednostek w znaczeniu ich zdolności produkcyjnej (w zakresie pośredniej produkcji człowieka), a może po prostu... wartość użytkowa. Im więcej czasu wolnego, tym większa siła produkcyjna pracy, a im większa siła produkcyjna pracy, tym większa (wytworzona przez nią) wartość użytkowa (w aspekcie ilościowym, jakościowym bądź w jednym i drugim). Uszczuplenie czasu pracy nie będzie godzić w wielkość wartości użytkowej, albowiem:

a) po pierwsze: tworzenie rzeczywistego bogactwa (czyli: bogactwa użytkowego) staje się - w miarę rozwoju wielkiego przemysłu - w mniejszym stopniu zależne 
od ilości zużytej pracy, a w coraz większym - od potęgi sił napędowych uruchamianych w czasie pracy

b) po drugie: oszczędność czasu pracy jest „identyczna z rozwojem siły wytwórczej”.

A zatem czas wolny nie dlatego będzie „miernikiem” rzeczywistego bogactwa, gdyż funkcją jego wielkości będzie wielkość ludzkich dyspozycji twórczych jako takich (czyli rozpatrywanych niezależnie od możliwości ich zastosowania w procesie pośredniej produkcji człowieka), ale dlatego, że funkcją jego wielkości będzie wielkość bogactwa użytkowego. Wychodzi na to, iż rzeczywistym bogactwem jest jednak - wbrew tezie drugiej - wartość użytkowa.

Zdaniem Jana Daneckiego wypowiedzi Marksa z Grundrisse o czasie wolnym składają się na tezę, że

8 „W miarę rozwoju wielkiego przemysłu tworzenie rzeczywistego bogactwa staje się jednak w mniejszym stopniu zależne od czasu pracy i od ilości użytej pracy aniżeli od potęgi sił napędowych uruchamianych w czasie pracy, które same z kolei - ich powerful effectiveness [potężna efektywność] - nie pozostają w żadnym stosunku do bezpośredniego czasu pracy potrzebnego do jego produkcji, lecz zależą raczej od ogólnego stanu nauki i od postępu technicznego, czyli od zastosowania tej nauki do produkcji. [...] Rzeczywiste bogactwo przejawia się raczej i wielki przemysł to odsłania - w ogromnej ilościowej dysproporcji między zużytym czasem pracy a jej produktem $i$, podobnie, w jakościowej dysproporcji między sprowadzoną do czystej abstrakcji pracą a potęgą kontrolowanego, nadzorowanego przez nią procesu produkcji. Praca stanowi już nie tyle część produkcji, ile raczej człowiek uczestniczy w procesie produkcji jako nadzorca i sterujący [regulator]. [...] Nie jest już [robotnik] głównym czynnikiem procesu produkcji, działa natomiast obok tego procesu. W tym przeobrażeniu nie bezpośrednia praca wykonywana przez samego człowieka i nie przepracowany przezeń czas tworzą wielką podwalinę produkcji i bogactwa, lecz zawłaszczanie przezeń własnej ogólnej siły wytwórczej, poznanie przezeń przyrody oraz opanowywanie jej dzięki swemu istnieniu jako organu społecznego - słowem, podwalinę tę tworzy rozwój społecznego indywiduum. Kradzież cudzego czasu pracy, na której opiera się obecne bogactwo, okaże się misérable [nikłą] podstawą w porównaniu z nowo rozwiniętą podstawą stworzoną przez wielki przemysł. $\mathrm{Z}$ chwilą, gdy praca w bezpośredniej postaci przestaje być wielkim źródłem bogactwa, czas pracy przestaje i musi przestać stanowić jego miarę, a zatem i wartość wymienna [przestaje być miarą] wartości użytkowej. Praca dodatkowa mas przestaje być warunkiem rozwoju ogólnego bogactwa, podobnie jak nie-praca niewielu przestaje być warunkiem rozwoju ogólnych mocy ludzkiej głowy. Załamuje się przez to produkcja oparta na wartości wymiennej, a bezpośredni materialny proces produkcji wyzbywa się form niedostatku i antagonizmu. Rozwijają się swobodnie indywidualności, toteż następuje skracanie czasu niezbędnego nie gwoli uzyskiwania pracy dodatkowej, lecz w ogóle skracanie do minimum czasu niezbędnego społeczeństwa, odpowiednio do artystycznego, naukowego itd. wykształcenia indywiduów, uzyskanego dzięki czasowi zwolnionemu dla nich wszystkich i dzięki stworzonym środkom”. Ibidem, s. 572-573.

9 „Rzeczywista ekonomia - oszczędność - polega na oszczędności czasu pracy (minimum i zmniejszanie do minimum - kosztów produkcji); oszczędność ta jest jednak identyczna z rozwojem siły wytwórczej. A więc nie jest ona w żadnym razie wyrzeczeniem się spożycia, lecz rozwijaniem power [energii], zdolności do produkcji, a zatem zarówno możności, jak i środków konsumpcji. Możność konsumowania jest warunkiem konsumpcji, a więc pierwszym środkiem konsumpcji, a możność ta jest wynikiem rozwoju indywidualnych uzdolnień, siły twórczej”. Ibidem, s. 578. 
miernikiem bogactwa przestaje być czas pracy bezpośredniej, a staje się nim czas wolny - traktowany jako sfera rozwoju catej różnorodności sit i zdolności ludzkich, niezbędnych do zrozumienia nader skomplikowanych warunków nowoczesnej produkcji i tym samym - do jej petnego opanowania. Teza ta nie dotyczy zatem czasu wolnego in abstracto, w żadnym zaś razie takiego spędzania wolnego czasu, jaki Anglosasi zwykli określać trafnym terminem time killing (zabijanie czasu). Nie odnosi się również do każdego sposobu wytwarzania. Uzyskuje ona sens dopiero przy takiej organizacji produkcji, która zakłada realne zastosowanie rozwiniętych w czasie wolnym zdolności i sił wytwórczych człowieka pracy. To właśnie dzięki tej nowej okoliczności - dzięki pełnemu włączeniu energii twórczej samych producentów - może nastąpić to kolosalne przyśpieszenie rozwoju sił wytwórczych, które powoduje, że „chociaż produkcja będzie teraz obliczona na bogactwo wszystkich, niemniej jednak wzrośnie czas wolny wszystkich"10.

W tym miejscu, mówiąc obrazowo, „cykl” rozpoczyna się niejako od nowa: uzyskany czas wolny powoduje dalszy rozwój „siły produkcyjnej każdego”, co z kolei prowadzi do pogłębienia twórczego charakteru pracy; w rezultacie osiąga się nowe przyśpieszenie rozwoju sił wytwórczych, nową oszczędność czasu pracy bezpośredniej, zwiększenie czasu wolnego wszystkich... ${ }^{11}$

Chodzi zatem nie o dyspozycje twórcze jako takie, ale o dyspozycje twórcze przekładające się na umiejętności wytwórcze (stosowane w procesie pośredniej produkcji człowieka), których wartość polega ostatecznie na tym, iż wzmagają one produkcję bogactwa rzeczywistego, którym okazuje się bogactwo użytkowe (nie zaś bogactwo „sił ludzkich" jako takich).

Czy nie mamy tu jednak do czynienia z nawrotem do potępianego przez Marksa poglądu „współczesnego”, czyli apologią produkcji burżuazyjnej - tyle że bez wartości wymiennej? Produkcji, na gruncie której człowiek nadal jest środkiem wytwarzania bogactwa, a nie jego nosicielem? Owszem, można by utrzymywać, iż za tezą głoszącą, iż po załamaniu się produkcji opartej na wartości wymiennej rzeczywistym bogactwem stanie się wartość użytkowa kryje się „w ostatniej instancji” teza, iż rzeczywistym bogactwem będzie sam czlowiek - jako konsument wszelakich wartości użytkowych. Celem wartości użytkowej jest przecież konsumpcja, czyli bezpośrednia produkcja człowieka. Bogactwo użytkowe jest tylko środkiem wytwarzania bogactwa podmiotowego. Ale „konsumpcjonistyczne” ujęcie bogactwa podmiotowego wydaje się ujęciem problematycznym, gubiącym twórczy wymiar ludzkiej praxis.

10 W thumaczeniu Wyrozembskiego zacytowany tu fragment z Grundrisse brzmi: „chociaż produkcja obliczona będzie na bogactwo dla wszystkich, to disposable time wszystkich będzie się zwiększał". K. Marks, Zarys krytyki..., s. 575.

11 J. Danecki, Jedność podzielonego czasu, Warszawa 1970, s. 59-60. 
Trzymając się ściśle komunistycznego punktu widzenia (czyli punktu widzenia prawdziwego sposobu produkcji), powinniśmy przyjąć, iż choć dyspozycje twórcze indywiduów mogą mieć również wartość instrumentalną (o ile wspierają proces pośredniej produkcji człowieka), to jednak mają one - przede wszystkim - wartość samoistną, stanowią bowiem substancję bogactwa rzeczywistego - i owa samoistna wartość nie ulega żadnemu uszczupleniu w przypadku ewentualnej bezużyteczności tych dyspozycji w ramach tak zwanej produkcji materialnej. Dyspozycje twórcze nieprzekładalne na umiejętności produkcyjne (pożytkowane na gruncie tzw. produkcji materialnej) nie są mniej wartościowe od tych dyspozycji, które dodatnio wpływają na produkcyjną siłę pracy. Wszelkie dyspozycje twórcze (a nawet szerzej: „,wszystkie siły ludzkie") mają wartość samoistną, są bogactwem rzeczywistym - niezależnie od możliwości ich zastosowania w procesie tak zwanej produkcji materialnej. Rozwój „sił ludzkich” - jak pamiętamy z wcześniej cytowanej wypowiedzi - ma być przecież „,elem samym w sobie”, a nie wyłącznie „środkiem” procesu produkcji rzeczy użytecznych (choć oczywiście nie tracąc rangi „celu samego w sobie”, może być on zarazem ,środkiem” procesu produkcji wartości użytkowych) - o tyle też rozwój dyspozycji twórczych nie może być sprowadzany do roli momentu procesu reprodukcji siły roboczej. Skoro produktem „ostatecznym” jest człowiek, właściwości stanowiące o jego bogactwie nie muszą legitymować się jakimikolwiek walorami dodatkowymi, nie muszą służyć żadnym celom „zewnętrznym” w stosunku do procesu jego samorealizacji twórczej. Pośrednia produkcja człowieka musi być oceniana pod kątem jej użyteczności dla procesu bezpośredniej produkcji człowieka: środki utrzymania mają efektywnie reprodukować życie materialne (jako substrat bogactwa rzeczywistego), a środki samorealizacji twórczej mają wspomagać samorealizację twórczą, czyli stymulację rozwoju dyspozycji twórczych. Natomiast ściśle produkcyjne ogniwo bezpośredniej produkcji człowieka (czyli „wznioślejsza działalność” stymulująca rozwój dyspozycji twórczych) może, ale wcale nie musi służyć pośrednio (ubocznie) ,interesom” pośredniej produkcji człowieka.

Jeżeli mimo to Marks uporczywie podkreśla instrumentalną wartość dyspozycji twórczych jednostki i (stymulującej ich rozwój) „wznioślejszej działalności” (podejmowanej w czasie wolnym), to mamy tu do czynienia z zabiegiem odwrotnym do tego, jakiego dokonuje on wówczas, gdy stwierdza, iż ostatecznym rezultatem produkcji burżuazyjnej jest „sam człowiek w jego więzi społecznej”, gdy przyjmuje, iż ostatecznymi „podmiotami” produkcji burżuazyjnej są same indywidua, że owa burżuazyjna produkcja jest ,nieustannym procesem ruchu, w którym indywidua odnawiają siebie samych". O ile bowiem w przywołanych tu sformułowaniach Marks spogląda na produkcję burżuazyjną w sposób antycypujący przyszłą produkcję komunistyczną (jako autoprodukcję - autokreację - indywiduów wytwarzających własne bogactwo podmiotowe, bogactwo swych „sił ludzkich”, „sił twórczych” itd.), o tyle rozważając wpływ czasu wolnego na siłę produkcyjną pracy, przykłada on 
do produkcji komunistycznej (albowiem gdy mowa o „wznioślejszej działalności” uprawianej przez robotników w czasie wolnym, to mowa nie o zjawisku typowym dla społeczeństwa kapitalistycznego, ale o zjawisku jeszcze niewystępującym, postulowanym przez Marksa w odniesieniu do komunistycznej przyszłości) „miarkę” właściwą produkcji burżuazyjnej, a więc instrumentalizuje rozwój człowieka, interpretując go jako proces rozszerzonej reprodukcji siły roboczej.

Mamy zatem dwa krzyżujące się spojrzenia: spojrzenie na produkcję burżuazyjną „oczami” produkcji komunistycznej i spojrzenie na produkcję komunistyczną „oczami" produkcji burżuazyjnej. Podejmowana tu rekonstrukcja teorii produkcji z Grundrisse (teorii dochodzącej do głosu, jak już wskazywałem, jedynie mimochodem; teorii, którą zatem „wyrywamy z kontekstu” i „absolutyzujemy” - otwarcie się do tego przyznając) jest oczywiście rekonstrukcją spojrzenia pierwszego (w postaci czystej, a więc takiej, która u Marksa faktycznie nie występuje). Interesować nas będzie nie tyle produkcja komunistyczna jako taka, ile produkcja burżuazyjna widziana „oczami” produkcji komunistycznej. Spoglądanie na produkcję burżuazyjną „oczami” produkcji komunistycznej jest alternatywą dla spoglądania na produkcję burżuazyjną jej własnymi „oczami”.

W świetle tezy trzeciej możemy nieco uszczegółowić nasz schemat produkcji globalnej. Produkcja nr 4 to - jak stwierdziliśmy - twórczość artystyczna i naukowa. Twórczość ta jest jednak trudna do pomyślenia bez kształcenia odpowiednich dyspozycji warsztatowych. Również kształcenie tych dyspozycji wypada zaliczyć do produkcji nr 4 jako jej drugie odgałęzienie - obok samej twórczości - obydwie stymulują bowiem bogactwo rzeczywiste (dyspozycje twórcze), czyli są procesami bezpośrednio wartościotwórczymi. Przy okazji możemy uszczegółowić produkcję nr 3, dzieląc ją na konsumpcję środków utrzymania oraz pracę reprodukcyjną, której uzupełnieniem jest edukacja elementarna i zawodowa. I tu niezbędny wydaje się komentarz wyjaśniający, dlaczego pewne edukacje (elementarna i zawodowa) zaliczone zostały do produkcji nr 3, gdy edukacja w zakresie dyspozycji twórczych należy do produkcji $\mathrm{nr}$ 4. Granica między produkcją $\mathrm{nr} 3$ i produkcją $\mathrm{nr} 4$ to, ujmując rzecz w terminach neutralnych - a więc nierozstrzygających - czy produkcja $\mathrm{nr} 3$ ma służyć produkcji $\mathrm{nr}$ 4, to znaczy być produkcją materialnego substratu „wznioślejszej działalności”, czy też (jako reprodukcja siły roboczej) ma służyć produkcjom nr 1 i 2 (dostarczając im siły roboczej) - granica między produkcją ciała a produkcją osobowości. Wszelka edukacja (poza wychowaniem fizycznym) wydaje się raczej produkcją osobowości niż produkcją ciała, czyli: cała edukacja winna być zaliczona do produkcji nr 4. Nasz schemat ujmuje jednak produkcję ciał nieco szerzej, a mianowicie jako produkcje ciał umiejacych się reprodukować, a więc ciał umiejących wytwarzać środki produkcji ciał (środki utrzymania), czyli ciał umiejących pracować w ramach produkcji nr 1 (przy założeniu, iż nie ma istotnej różnicy między umiejętnością pracy w ramach produkcji nr 1 a umiejętnością pracy $\mathrm{w}$ ramach produkcji $\mathrm{nr} 2$, są to zarazem ciała 
umiejące pracować w ramach produkcji nr 2). Umiejętność pracy w produkcji nr 1 wymaga edukacji elementarnej i zawodowej - co uzasadnia zaliczenie tych edukacji do tej samej kategorii, w której mieści się konsumpcja środków utrzymania wraz $\mathrm{z}$ towarzyszącą jej pracą organizacyjną (pracą reprodukcyjną). Natomiast edukacja w zakresie dyspozycji twórczych nie należy do produkcji ciał umiejących się reprodukować, albowiem ani nie wytwarza ciał (jak konsumpcja środków utrzymania), ani też - wbrew pewnym wypowiedziom Marksa - nie wyposaża ciał w dyspozycje przydatne w procesie ich reprodukcji (jak edukacje elementarna i zawodowa).

\begin{tabular}{|l|l|l|l|}
\hline \multicolumn{3}{|c|}{ Globalna produkcja człowieka } \\
\hline \multicolumn{2}{|c|}{ Pośrednia produkcja człowieka } & \multicolumn{1}{c|}{ Bezpośrednia produkcja człowieka } \\
\hline $\begin{array}{l}\text { Produkcja środków } \\
\text { utrzymania }\end{array}$ & $\begin{array}{l}\text { Produkcja środków } \\
\text { samorealizacji } \\
\text { twórczej }\end{array}$ & $\begin{array}{l}\text { Materialna } \\
\text { reprodukcja } \\
\text { człowieka }\end{array}$ & $\begin{array}{l}\text { Produkcja dyspozycji } \\
\text { twórczych człowieka } \\
\text { (produkcja rzeczywistego } \\
\text { bogactwa) }\end{array}$ \\
\hline
\end{tabular}

\begin{tabular}{|l|l|l|l|}
\hline $\begin{array}{l}\text { Konsumpcja } \\
\text { środków } \\
\text { utrzymania }\end{array}$ & $\begin{array}{l}\text { Praca reprodukcyjna }+ \\
\text { edukacja elementarna } \\
\text { i zawodowa }\end{array}$ & $\begin{array}{l}\text { Kształcenie warsztatowych } \\
\text { dyspozycji twórczych } \\
\text { (w zakresie twórczości } \\
\text { artystycznej i naukowej) }\end{array}$ & $\begin{array}{l}\text { Działalność } \\
\text {,wznioślejsza”, czyli } \\
\text { twórczość artystyczna } \\
\text { i naukowa }\end{array}$ \\
\hline
\end{tabular}

Skoro mówimy tu o produkcji burżuazyjnej widzianej „oczami” produkcji komunistycznej (a nie o samej produkcji komunistycznej), wypada podkreślić pewien oczywisty fakt: przeciętny uczestnik produkcji $n r 1$, czyli robotnik, nie jest w ogóle podmiotem/produktem produkcji $\mathrm{nr}$ 4. Jest on niewątpliwie produktem produkcji $\mathrm{nr}$ 3 produkującej - z burżuazyjnego punktu widzenia - siłę roboczą, a z komunistycznego punktu widzenia - materialny substrat bogactwa rzeczywistego (bez samego bogactwa). Z komunistycznego punktu widzenia (w świetle którego wszelka produkcja jest produkcją człowieka, a jedynym bezpośrednio wartościotwórczym ogniwem produkcji człowieka jest produkcja bogatej osobowości ludzkiej, w szczególności: produkcja dyspozycji twórczych) przeciętny robotnik kapitalistyczny jest zaledwie nagim substratem - nosicielem niczego.

Podmiot/produkt produkcji nr 4 albo w ogóle nie uczestniczy w produkcji nr 1, albo jest jej uczestnikiem zupełnie nietypowym - posiadającym właściwości nietypowe dla zbiorowości uczestników produkcji nr 1. Klasa robotnicza albo w ogóle nie dysponuje czasem wolnym, albo pozbawiona jest możliwości podejmowania w czasie wolnym jakiejkolwiek „wznioślejszej działalności”. To samo dotyczy zresztą klasy kapitalistycznej: przeciętny kapitalista również nie podejmuje „wznioślejszej działalności”, jest bowiem pochłonięty działalnością zupełnie prozaiczną: „robieniem pieniędzy", doglądaniem kapitału. Natrafiamy zatem na ślad innego podziału klasowego niż ten, na który wskazuje „Zwykła” teoria produkcji. Uczestnicy pro- 
dukcji nr 4 są niewątpliwie bogaczami - nosicielami bogactwa rzeczywistego, czyli ludźmi wielce uprzywilejowanymi, podczas gdy ludzie z produkcji tej wyłączeni a są to: przeciętni robotnicy i przeciętni kapitaliści - walczą o bogactwa pozorne (zaledwie przedmiotowe): wartość wymienną i wartość użytkową.

Zanim jednak pociągniemy ten wątek, powinniśmy nieco uzupełnić prezentowaną tu teorię produkcji, a więc, po pierwsze, zastanowić się nad produktami ubocznymi poszczególnych produkcji (komplikującymi obraz relacji między nimi i zacierającymi - do pewnego stopnia - wyraźną granicę między pośrednimi i bezpośrednimi produkcjami człowieka), po drugie, zreinterpretować (w świetle formułowanych tu założeń odnośnie do produkcji) tradycyjne marksistowskie rozumienie „środków produkcji”.

\section{Produkty uboczne}

Trzymaliśmy się dotychczas założenia, iż produktem bezpośredniej produkcji człowieka jest człowiek (produktem produkcji nr 3 jest ciało czy po prostu życie jako takie - materialny substrat rzeczywistego bogactwa, a produktem produkcji $\mathrm{nr} 4$ bogata osobowość ludzka), natomiast produktem pośredniej produkcji człowieka produkt pozaludzki, którego późniejsza konsumpcja należy do procesu bezpośredniej produkcji człowieka. Sytuacja nie przedstawia się jednak tak prosto.

Ubocznym produktem produkcji nr 4 jest bowiem specyficzny produkt pozaludzki, a mianowicie dzieło (naukowe bądź artystyczne). Produkt tego rodzaju wypada zaliczyć do kategorii środków samorealizacji twórczej, albowiem dzieło będące eksterioryzacją osobnika $\mathrm{x}$ - zinterioryzowane przez osobnika y - może stać się środkiem eksterioryzacji (czyli samorealizacji twórczej) osobnika y. Niezbędny jest tu pewien komentarz. Gdy stwierdzamy, iż dzieło jest ubocznym produktem produkcji nr 4 (a bogata osobowość jej produktem zasadniczym), trzymamy się punktu widzenia prawdziwego sposobu produkcji, nie zaś punktu widzenia jednostki działającej w jego obrębie. Dla samorealizującej się twórczo jednostki celem zasadniczym, a nawet jedynym, może być - tworzone przez nią - dzieło, natomiast jej własny rozwój osobowościowy (osiągnięty w procesie tworzenia dzieła) może być (dla niej samej) nieistotnym produktem ubocznym. Tymczasem odnośnie do (poddawanego tu pewnej antropomorfizacji) prawdziwego sposobu produkcji zakładamy, iż jego celem nie są wcale bogate dzieła, ale bogaci ludzie (tworzenie bogatego dzieła jest tylko środkiem samowytwarzania się bogatego człowieka), a być może nawet: nie tyle ludzie bogaci, ile ludzie samorealizujący się, czyli poświęcający się własnym zainteresowaniom twórczym (celem nie jest więc osiąganie przez jednostki stanu bogactwa, ile sam całożyciowy proces bogacenia się, a właściwie nie tyle proces bogacenia się, ile proces samorealizacji; towarzyszące samorealizacji bogacenie się, czyli rozwijanie dyspozycji twórczych, prowadzące do osiągnięcia przez jednostkę stanu pełnego rozwinięcia jej dyspozycji twórczych, byłoby - przy tym założeniu - procesem ubocz- 
nym). W dalszych rozważaniach będziemy się jednak trzymać (upraszczającego) założenia, iż celem prawdziwego sposobu produkcji są bogaci ludzie.

Ale również produkcje nr 1 i 2 mają swój produkt uboczny, z uwagi na który produkcje te (ujmowane przez nas jako pośrednie produkcje człowieka) są zarazem bezpośrednimi produkcjami człowieka. Marksowska krytyka pracy wyalienowanej i społecznego podziału pracy bardzo wyraźnie wskazuje na okoliczność, iż proces pracy wyalienowanej, cząstkowej jest zarazem procesem produkcji osobowości, tyle że nie jest to wcale produkcja osobowości bogatej, ale produkcja osobowości ubogiej, jednostronnej, zdeformowanej. Z uwagi na ten swój aspekt produkcje nr 1 i 2 podpadają pod produkcję nr 4 jako - należące do jej dziedziny - kontrprodukcje. Przeciętny uczestnik produkcji nr 1 i 2 (o którym zakładamy, iż jest wyłączony z produkcji $\mathrm{nr} 4$ ) - robotnik - nie jest więc zupełnie nagim substratem materialnym, nosicielem braku osobowości - jest raczej nosicielem osobowości okaleczonej. Jeżeli normalna produkcja nr 4 polega na rozwijaniu, pielęgnowaniu przyrodzonych zdolności jednostki, kontrprodukcja nr 4 (jako moment produkcji nr 1 i 2) polega na ich niszczeniu, na przeciwdziałaniu ich aktualizacji. Nie ma w tym w gruncie rzeczy nic osobliwego - wszelka produkcja jest przecież w określonym zakresie procesem destrukcji. Nie ma też nic osobliwego w tym, iż produktem produkcji jest nie tylko bogactwo, ale również ubóstwo, czyli że ubóstwo może być nie tylko produktem braku (czy niedorozwoju) produkcji, ale też produktem produkcji. Odnosi się to zarówno do bogactw/ubóstw przedmiotowych (zjawisko ubóstwa materialnego jest przecież rezultatem historycznego rozwoju produkcji bogactwa materialnego), jak i bogactw/ ubóstw podmiotowych, osobowościowych. O ubóstwie osobowościowym założyliśmy, iż może być ono nie tylko rezultatem zaniechania produkcji bogactwa osobowościowego, ale także rezultatem systematycznego karczowania potencji twórczych (z którymi jednostka przychodzi na świat) towarzyszącego produkcjom nr 1 i 2 . Produkowanie ubóstwa jest osobliwością jedynie z komunistycznego punktu widzenia, czyli z punktu widzenia prawdziwego sposobu produkcji.

Oczywiście produkcje nr 1 i 2 obejmują również prace, które można interpretować jako zupełnie analogiczne do działań zaliczonych do normalnej produkcji $\mathrm{nr} 4$. Chodzi w szczególności o pracę projektanta środków utrzymania bądź środków samorealizacji twórczej (o którym zakłada się, iż realizuje się twórczo). Czy twórczość podporządkowana zadaniu wytwarzania wartości użytkowej może być taką samą twórczością jak twórczość swobodna? Czy może wytwarzać takie samo bogactwo rzeczywiste? Tej sprawy nie będziemy tu rozważać. Podkreślić jednak należy, iż ideą ortodoksyjnie marksistowską jest idea dezalienacji pracy, czyli - w przełożeniu na proponowaną tu terminologię - idea upodobniania pracy w procesie pośredniej produkcji człowieka do (normalnej) produkcji nr 4, czemu sprzyjać mają socjalistyczne/ komunistyczne stosunki społeczne oraz rewolucja naukowo-techniczna. 
Również produkcja $\mathrm{nr} 3$ ma pewien pominięty w dotychczasowych rozważaniach rezultat analogiczny do ubocznego rezultatu pośrednich produkcji człowieka. Konsumpcja środków utrzymania może być nie tylko wytwarzaniem materialnego substratu bogactwa osobowościowego, ale też produkcją osobowościowego ubóstwa (nawiasem mówiąc, może być ona - jako konsumpcja nadmiarowa - także destrukcją samego substratu materialnego). Marks wskazuje z kolei - i to właśnie w Grundrisse - na możliwość przeciwną, a mianowicie na to, iż konsumpcja (wyrafinowanych) środków utrzymania niebędących już środkami utrzymania w ścisłym tego słowa znaczeniu jest również produkcją bogatej indywidualności:

W niezmordowanym jednak dążeniu do ogólnej formy bogactwa kapitał gna pracę poza jej naturalną konieczność i stwarza w ten sposób materialne elementy dla rozwoju bogatej indywidualności, wszechstronnej zarówno w dziedzinie swej produkcji, jak i swej konsumpcji; dla tej wszechstronnej indywidualności praca nie jest już więcej pracą, lecz jest pełnym rozwinięciem działalności, w której zanikła przyrodnicza konieczność w swej bezpośredniej formie, bowiem w miejsce potrzeb uwarunkowanych przyrodniczo wkroczyły potrzeby stworzone historycznie ${ }^{12}$.

Wypowiedź ta, wypada zaznaczyć, zaciera wyraźną granicę między środkiem utrzymania a środkiem samorealizacji twórczej - posiadającą istotne znaczenie w ramach rozwijanej tu konstrukcji teoretycznej. Pod pojęciem „potrzeb stworzonych historycznie" (wkraczających w miejsce „potrzeb uwarunkowanych przyrodniczo") można bowiem rozumieć zarówno potrzeby w zakresie samorealizacji twórczej i konsumpcji dzieł będących owocem samorealizacji twórczej innych jednostek (mogących inspirować samorealizację twórczą ich konsumentów), jak i potrzeby w zakresie konsumpcji luksusowej. Marks jest, jak wiadomo, zwolennikiem rozwijania (i zaspokajania) przez ludzkość najróżnorodniejszych potrzeb, a więc też tych, które określa się niekiedy jako „sztuczne” (czyli „niepotrzebne”, ,nienaturalne”). Bogactwo (rozwój, wszechstronność) człowieka utożsamia on w gruncie rzeczy z bogactwem ludzkich potrzeb. Rozwój ludzkich potrzeb jest także dla niego miarą historycznego postępu. W Rękopisach ekonomiczno-filozoficznych czytamy: „Widzimy, że miejsce ekonomicznego bogactwa i nędzy zajmuje bogaty człowiek i bogata potrzeba ludzka. Bogaty człowiek jest zarazem człowiekiem potrzebującym pełni przejawów ludzkiego życia, człowiekiem, w którym jego własne urzeczywistnienie istnieje jako wewnętrzna konieczność, jest człowiekiem w potrzebie"13.

W taki oto sposób młody Marks krytykuje ekonomię polityczną:

12 K. Marks, Zarys krytyki..., s. 238.

13 K. Marks, Rękopisy ekonomiczno-filozoficzne z 1844 r., w: K. Marks, F. Engels, Dzieła, t. I, Warszawa 1976, s. 586-587. 
Ekonomia polityczna jest więc [...] nauką prawdziwie moralną, najmoralniejszą z nauk. Jej podstawową zasadą jest samowyrzeczenie, wyrzeczenie się życia i wszelkich ludzkich potrzeb. Im mniej jesz, pijesz, kupujesz książek, im rzadziej chodzisz do teatru, na bal, do gospody, im mniej myślisz, kochasz, teoretyzujesz, śpiewasz, malujesz, układasz wierszy, tym więcej oszczędzasz, tym większy staje się twój skarb, którego ani mól nie zje, ani robak nie stoczy - kapitat. Im mniej jesteś, im słabiej przejawiasz swoje życie, tym więcej masz, tym większe jest twoje wyalienowane życie, tym więcej gromadzisz swej wyalienowanej istoty. Wszystko, co ekonomista zabiera ci z życia i człowieczeństwa, zwraca ci w pieniadzach i w bogactwie... ${ }^{14}$

Marks nie jest zatem zwolennikiem rozwijania potrzeb samorealizacyjnych kosztem konsumpcyjnych, ale rzecznikiem rozwoju jednych i drugich prowadzącego do zatarcia wyraźnej różnicy między nimi.

Nasza konstrukcja teoretyczna - wbrew tej tendencji - wyraźnie oddziela środki samorealizacji twórczej od środków utrzymania. Pojawia się jednak problem interpretacji przedmiotów konsumpcji wytwarzanych przez tak zwaną kulturę masową, które możemy określić mianem pseudo-dzieł albo wyrobów dziełopodobnych ${ }^{15}$. Choć zasadniczo nie są to ani zwykłe środki utrzymania, ani środki samorealizacji twórczej (aczkolwiek i w takiej roli mogą czasem występować), zaliczamy je raczej do kategorii środków utrzymania - konsumowanych w procesie reprodukcji siły roboczej. Reprodukcja siły roboczej (przynajmniej w kapitalizmie) wymaga nie tylko środków zaspokajających potrzeby ciała, czyli potrzeby: jedzenia, picia, okrycia ciała, dachu nad głową itd., ale również środków zaspokajających potrzebę regeneracji -

14 Ibidem, s. 593.

15 Czy samo wytwarzanie pseudo-dzieł podpada pod produkcję $\mathrm{nr} 4$ ? Jeżeli twórca pseudo-dzieła reprezentuje równie niski poziom w zakresie umiejętności tworzenia jak jego publiczność (w zakresie umiejętności odbioru), jeżeli ubogie treści, które usiłuje zawrzeć w swym pseudo-dziele, wiernie oddają jego własne ubóstwo wewnętrzne, jeżeli gusta publiczności, dla której tworzy, są jego własnymi gustami - wytwarzanie pseudo-dzieła można oceniać jako pełnowartościowy proces eksterioryzacyjny stymulujący rozwój dyspozycji twórczych (czy ogólniej: akumulację bogactwa osobowościowego) twórcy. Twórca startuje z pułapu bardzo niskiego, niemniej.. startuje, czyli - jak można domniemywać - rozwija się. Jeżeli jednak twórcą pseudo-dzieła jest prawdziwy artysta, który tworzy (dane pseudo-dzieło) wyłącznie dla pieniędzy (by uzyskać środki, dzięki którym będzie mógł poświęcić się prawdziwej twórczości - adresowanej do innej publiczności), jeżeli w trakcie tworzenia pseudo-dzieła artysta bezustannie poddaje się autocenzurze, celowo zaniża loty, by utrafić w rynkowe zapotrzebowanie, jeżeli ogranicza się do kopiowania gotowych schematów itd. - nie ma tu mowy o żadnej eksterioryzacji i o żadnym rozwoju - o artyście tym należy założyć, iż eksterioryzuje się i rozwija w ramach innych procesów twórczych. Jak widać, sens określenia „pseudo-dzieło” zmienia się w zależności od tego, który przypadek mamy na względzie. W przypadku pierwszym „,pseudo-dzieło” to po prostu dzieło marne, trafiające w niskie gusta, mające walory wyłącznie rozrywkowe. W przypadku drugim ,pseudo-dzieło” to ponadto produkt twórczości nieautentycznej, pozbawionej znamion prawdziwej eksterioryzacji. 
znużonego intensywną pracą - „ducha”; tę ostatnią potrzebę - nazwijmy ją potrzebą rozrywki - zaspokaja przemysł rozrywkowy będący szczególnym odgałęzieniem produkcji nr 1 .

Wspominając o produkcji nr 3 i jej ubocznym produktach (ubóstwie i bogactwie osobowościowym), mówiliśmy dotychczas wyłącznie o samej konsumpcji. Ale produkcja nr 3 to nie tylko konsumowanie, ale też praca reprodukcyjna. Wykonywanie pracy reprodukcyjnej na rzecz innych osób (męża, dzieci) może być takim samym wytwarzaniem ubóstwa osobowościowego jak wykonywanie prac na gruncie produkcji nr 1 i 2. Tę okoliczność miał na względzie Włodzimierz Lenin, pisząc:

[kobiety] są „,niewolnicami domowymi”, gdyż przytlacza je najbardziej monotonna, najczarniejsza, najcięższa i najbardziej otępiająca człowieka praca w kuchni i w ogóle w odizolowanym rodzinnym gospodarstwie domowym ${ }^{16}$.

Kobieta jest jeszcze wciąż niewolnica domowa, mimo wszystkich wyzwalających ją ustaw, ponieważ przytłacza ją, dusi, ogłupia, poniża drobne gospodarstwo domowe, które przykuwa ją do garnków i pieluch, trwoni jej wysiłek na pracę wręcz barbarzyńsko nieprodukcyjną, drobną, denerwującą, otępiającą, ogłupiającą ${ }^{17}$.

To gospodarstwo domowe jest zazwyczaj najbardziej nieproduktywną, najbardziej barbarzyńską, najcięższą pracą, wykonywaną przez kobietę. Jest to praca nadzwyczaj żmudna, niezawierająca w sobie niczego, co by choć trochę przyczyniało się do rozwoju kobiety ${ }^{18}$.

I jeszcze słowo o produkcji nr 2. Założyliśmy, iż produkcja nr 2 (jeżeli pominąć okoliczność, iż do kategorii środków samorealizacji twórczej zaliczyć wypada również dzieła) nie różni się - z uwagi na swoje uboczne rezultaty podmiotowe - od produkcji $\mathrm{nr} 1 . \mathrm{Z}$ punktu widzenia robotnika zatrudnionego w fabryce fortepianów nie ma większego znaczenia, iż produkowany przezeń fortepian posłuży komuś jako środek samorealizacji twórczej (podczas gdy jego kolega zatrudniony w fabryce mebli wytwarza prozaiczny środek utrzymania). Praca w produkcji nr 2 nie różni się istotnie od pracy w produkcji nr 1 - obie są w równym stopniu kontrprodukcjami $\mathrm{nr}$ 4. O wielu produktach (których oficjalne przeznaczenie zdaje się wskazywać na ich przynależność do kategorii środków samorealizacji twórczej) nie wiadomo zresztą, czy okażą się rzeczywistymi środkami samorealizacji twórczej, czy też środkami innego rodzaju praktyk konsumpcyjnych (fortepian może przecież służyć jako me-

16 W. Lenin, Międzynarodowy dzień robotnic, w: W. Lenin, Dzieła wszystkie, t. XLII, Warszawa 1988, s. 356.

17 W. Lenin, Wielka inicjatywa (o bohaterstwie robotników na zapleczu. Z okazji „,komunistycznych subotników”), w: W. Lenin, Dzieła wszystkie, t. XXXIX. Warszawa 1988, s. 22.

18 W. Lenin, O zadaniach kobiecego ruchu robotniczego w republice radzieckiej. Przemówienie na IV Moskiewskiej Ogólnomiejskiej Bezpartyjnej Konferencji Robotnic 23 września 1919 r., w: W. Lenin, Dzieła wszystkie, t. XXXIX, Warszawa 1988, s. 193. 
bel ozdobny). Z drugiej strony środkami samorealizacji twórczej mogą się okazać zwykłe środki utrzymania - użyte w sposób nietypowy (np. mebel zakupiony w celu przerobienia na rzeźbę). Wyodrębnienie produkcji nr 2 ma jednak sens w kontekście procesu transformacji produkcji burżuazyjnej w produkcję komunistyczną. O produkcji burżuazyjnej twierdzimy, iż jej cechą istotną jest podporządkowanie bezpośredniej produkcji ludzi pośredniej produkcji ludzi, natomiast produkcja komunistyczna - znająca prawdziwy cel produkcji - to taka produkcja, która maksymalizuje bezpośrednią produkcję człowieka, a wszelką pośrednią produkcję człowieka uznaje wyłącznie za środek. Z faktu podporządkowania (na gruncie produkcji burżuazyjnej) produkcji ludzi (nr 3 i 4) produkcji rzeczy (nr 1 i 2) wynika zarazem - w obrębie bezpośredniej produkcji człowieka - upośledzenie produkcji nr $4 \mathrm{w}$ stosunku do produkcji nr 3 znajdujące swój wyraz w całkowitym wyłączeniu olbrzymiej masy ludzi z udziału w produkcji nr 4, a nawet z konsumpcji jej rezultatów przedmiotowych/ ubocznych. Produkcja nr 3 (konsumująca produkty produkcji nr 1) jest - na gruncie produkcji burżuazyjnej - ważna z uwagi na potrzebę dostarczenia pośrednim produkcjom człowieka wielkiej armii nosicieli siły roboczej. Produkcja nr 4 nie odgrywa tej roli, więc pozostaje produkcją zaledwie niszową. Otóż niszowość produkcji nr 4 owocuje z kolei upośledzeniem produkcji nr $2 \mathrm{w}$ stosunku do produkcji $\mathrm{nr} 1$. Owszem, produkcja nr 2 wytwarza towary, których realizacja rynkowa pomnaża kapitał, jednak niszowość produkcji $\mathrm{nr} 4$ (konsumującej produkcyjnie produkty produkcji nr 2) radykalnie zawęża rynek dla tego rodzaju towarów, wskutek czego produkcja nr 2 pozostaje w cieniu produkcji nr 1. Przejście od produkcji burżuazyjnej do produkcji komunistycznej (a więc włączenie całej populacji do udziału w produkcji nr 4) musi znaleźć swój wyraz w istotnej zmianie proporcji między produkcją nr 1 i produkcją $\mathrm{nr} 2$ (a w obrębie samej produkcji nr 1: w malejącym znaczeniu produkcji rozrywkowych środków utrzymania).

I jeszcze jedna kwestia. Rozpatrując produkcję burżuazyjną z komunistycznego punktu widzenia, interpretujemy produkcję nr 3 nie jako reprodukcję siły roboczej (co odpowiadałoby burżuazyjnemu punktowi widzenia), ale jako produkcję materialnego substratu produkcji $\mathrm{nr} 4$, a ponadto również - w tym zakresie, $\mathrm{w}$ jakim konsumpcja wraz z pewnymi odmianami pracy reprodukcyjnej może być źródłem przyjemności - jako produkcję, której rezultat ma wartość samoistną (skoro człowiek jest celem, dobro człowieka - którym może być przyjemność - jest wartością samoistną, w związku z czym nie musi być środkiem żadnego innego procesu produkcyjnego). Wiemy jednak, że na gruncie produkcji burżuazyjnej - wbrew naszemu spoglądaniu na nią z komunistycznego punktu widzenia - produkcja nr 3 jest przede wszystkim procesem reprodukcji siły roboczej (i w tym zakresie komunistyczny punkt widzenia na produkcję burżuazyjną jest fałszywym punktem widzenia; jego fałszywość jest wynikiem jego prawdziwości przy jednoczesnej fałszywości celu produkcji burżuazyjnej). 
Szczegółowa analiza czynności wchodzących w skład produkcji nr 3 wykazałaby, że:

a) pewne czynności mogą służyć jednocześnie: 1) reprodukcji siły roboczej; 2) wytwarzaniu substratu bogactwa rzeczywistego; 3) przyjemności (przykład: jedzenie);

b) pewne czynności mogą służyć wyłącznie reprodukcji siły roboczej (edukacja ściśle zawodowa);

c) pewne czynności mogą służyć jednocześnie: 1) reprodukcji siły roboczej; 2) przyjemności (konsumpcja pseudo-dzieł kultury rozrywkowej);

d) pewne czynności mogą służyć jednocześnie: 1) reprodukcji siły roboczej; 2) wytwarzaniu substratu bogactwa rzeczywistego (edukacja elementarna).

Sformułowanie „mogą służyć” (zamiast „służą") nie jest tu przypadkowe. Pewne czynności - wchodzące w skład produkcji nr 3 - mogłyby służyć wytwarzaniu substratu produkcji $\mathrm{nr} 4$, gdybyśmy mieli do czynienia z realiami produkcji komunistycznej. Choć bowiem patrzymy na produkcję burżuazyjną „oczami” produkcji komunistycznej, jest to - faktycznie - produkcja burżuazyjna, a więc produkcja produkująca człowieka nie jako swój produkt docelowy (a więc taki, którego jakość ma być - w istniejących warunkach - optymalna), ale produkcja produkująca człowieka jako środek (a więc jako produkt, którego jakość może być marna - byle tylko dobrze spełniał swoją funkcję środka). Ponieważ pełnowartościowa produkcja człowieka jest tu zjawiskiem zupełnie niszowym, wytwarzanie (przez produkcję nr 3) substratu produkcji nr 4 jest (w absolutnej większości przypadków) wytwarzaniem substratu czysto potencjalnego, który nigdy nie stanie się substratem aktualnym. Tak jak produkcja nr 4 nie służy - na gruncie produkcji burżuazyjnej - doskonaleniu siły roboczej (wskazywana przez Marksa możliwość tego rodzaju odnosi się do produkcji komunistycznej widzianej „oczami” produkcji burżuazyjnej), tak też produkcja $\mathrm{nr}$ 3 - będąca faktycznie reprodukcją siły roboczej - nie służy wytwarzaniu substratu produkcji nr 4. (Przyczyna jest w obydwu przypadkach jednakowa: przeciętny robotnik nie jest w kapitalizmie podmiotem/produktem „wznioślejszej działalności”, a nawet jeżeli trafi się taki robotnik, który po godzinach uczestniczy w produkcji nr 4 , to produkcyjna siła jego pracy niewiele na tym skorzysta). Dlatego też interpretując produkcję nr 3 jako wytwarzanie substratu produkcji nr 4, raczej antycypujemy przyszłość, niż opisujemy teraźniejszość. Niewątpliwie jednak produkcja nr 3 nie jest na gruncie produkcji burżuazyjnej wyłącznie reprodukcją siły roboczej, bywa ona bowiem również źródłem przyjemności - przyjemności aktualnych (a nie zaledwie antycypowanych). Proces życia robotnika - na szczęście - nie sprowadza się do procesu reprodukcji siły roboczej, a nawet te przyjemności, które owej reprodukcji faktycznie służą, dla samego robotnika nie są środkami regeneracji jego siły roboczej, ale po prostu przyjemnościami. 


\section{Rodzaje środków produkcji}

Przez „środki produkcji” rozumiemy zazwyczaj środki pośredniej produkcji człowieka; środki o charakterze przedmiotowym (a więc istniejące na zewnątrz robotnika), obejmujące: środki pracy i przedmioty pracy ${ }^{19}$. Na gruncie rozwijanej tu konstrukcji teoretycznej będziemy rozumieć „środki produkcji” szerzej. „Środkami produkcji” będą zatem - oprócz środków produkcji używanych w procesach produkcji nr 1 i 2 także środki używane w procesach produkcji nr 3 i 4, a ponadto oprócz przedmiotowych środków produkcji też podmiotowe środki produkcji (czyli określone dyspozycje/umiejętności jednostek).

Relacje między rodzajami produkcji polegają przede wszystkim na tym, iż produkt produkcji x jest środkiem produkcji y, co oznacza, iż produkcja x jest produkcją pomocniczą produkcji y. Ta sama rzecz, która z punktu widzenia produkcji x jest produktem ostatecznym (gotowym przedmiotem konsumpcji), z punktu widzenia produkcji y jest środkiem produkcji.

Wychodzimy tu z założenia (odpowiadającego realiom prawdziwego sposobu produkcji), iż produktem „ostatecznym” produkcji globalnej jest człowiek, czyli jego ciało (produkt produkcji nr 3) i osobowość (produkt produkcji nr 4), przy czym jedynym procesem bezpośrednio wartościotwórczym jest produkcja bogactwa osobowościowego - produkcja $\mathrm{nr} 4$ (albowiem celem prawdziwego sposobu produkcji nie jest produkcja byle jakiego życia ludzkiego, czyli byle jakich ciał ludzkich, ale ciał wyposażonych w bogatą osobowość). Przy tym założeniu:

1. Produkcja $\mathrm{nr} 3$ jest produkcją pomocniczą produkcji $\mathrm{nr} 4$, albowiem dostarcza produkcji nr 4 ciało (materialny substrat osobowości), czyli przedmiot pracy, który jest następnie przetwarzany w toku produkcji $\mathrm{nr} 4$ (wyposażającej ciało w bogatą osobowość).

2. Produkcja nr 2 jest produkcją pomocniczą produkcji $\mathrm{nr} 4$, albowiem dostarcza produkcji nr 4 środki samorealizacji twórczej (np. fortepiany), które - na gruncie produkcji nr 4 - posłużą jako środki produkcji.

3. Produkcja nr 1 jest produkcją pomocniczą produkcji $\mathrm{nr} 3$, albowiem wytwarza środki utrzymania, które - na gruncie produkcji $\mathrm{nr} 3$ - posłużą jako środki produkcji (środki wytwarzania ciała).

To są relacje zasadnicze. Ale oprócz tego wskazaliśmy również na relacje dodatkowe wynikające z uwzględnienia produktów ubocznych poszczególnych produkcji:

19 „Prostymi momentami procesu pracy są: celowa działalność, czyli sama praca, przedmiot pracy i środki pracy”. „Środkiem pracy jest rzecz lub zespół rzeczy, które robotnik umieszcza między sobą a przedmiotem pracy i które służą mu za przewodniki jego oddziaływania na ten przedmiot”. „Jeżeli rozpatrywać cały proces z punktu widzenia jego wyniku, produktu, to zarówno środek pracy, jak i przedmiot pracy występują jako środki produkcji...”. K. Marks, Kapitat, t. I, w: K. Marks, F. Engels, Dzieta, t. XXIII. Warszawa 1968, s. 206, 207, 209. 
1. Produkcja nr 4 jest swoją własną produkcją pomocniczą, o ile wytwarza produkty analogiczne do produktów produkcji nr 2, czyli środki samorealizacji twórczej w postaci dzieł.

2. Produkcje nr 1,2 i 3 (jako praca reprodukcyjna) są kontrprodukcjami produkcji $\mathrm{nr} 4$, czyli produkcjami oddziałującymi na człowieka (który jest ich podmiotem) w sposób odwrotny do tego, w jaki oddziałuje na swój podmiot/przedmiot produkcja nr 4.

3. Produkcja nr 3 (jako praktyka konsumowania) może być zarówno kontrprodukcją produkcji nr 4, jak i jej uzupełnieniem.

Wreszcie wskazaliśmy na to, iż produkcja nr 3 , choć komunistyczny punkt widzenia nakazuje ujmować ją jako produkcję pomocniczą produkcji $\mathrm{nr} 4$, na gruncie produkcji burżuazyjnej (która jest naszym faktycznym przedmiotem) jest przede wszystkim produkcją pomocniczą produkcji nr 1 i 2 (którym dostarcza siły roboczej), a poniekąd też swoją własną produkcją pomocniczą.

Środki produkcji 1 i 2 nie stanowią żadnej tajemnicy, są bowiem stałym przedmiotem zainteresowania teorii marksistowskiej. W tej kwestii możemy co najwyżej przypomnieć, iż zaliczamy tu do nich także środki podmiotowe, czyli umiejętności produkcyjne jednostek (konsumowane przez produkcje nr 1 i 2), których źródłem jest sama praca (w produkcjach $\mathrm{nr} 1$ i 2 ), a ponadto edukacja elementarna i zawodowa (którą zaliczyliśmy do produkcji nr 3). Skoro mówimy o produkcji burżuazyjnej, nie mamy powodu uwzględniać uwag Marksa sugerujących, iż źródłem umiejętności produkcyjnych może być też „wznioślejsza działalność” w czasie wolnym, czyli produkcja nr 4 (z czego wynikałoby, iż dyspozycje twórcze wytwarzane przez produkcję $\mathrm{nr} 4$ są podmiotowymi środkami produkcji $\mathrm{nr} 1$ i 2). Tak będzie - być może - w komunizmie.

Skupmy się zatem na środkach bezpośrednich produkcji człowieka. Ze względów objętościowych pominiemy środki produkcji nr 3, do których można zaliczyć następujące produkty produkcji $\mathrm{nr} 1$ :

- gotowe środki konsumpcji (przedmioty konsumpcji),

- surowe środki konsumpcji (przedmioty pracy reprodukcyjnej),

- środki pracy reprodukcyjnej (służące do obróbki surowych środków konsumpcji).

Przedmiotem naszego zainteresowania będą środki produkcji nr 4. Przedmiotowymi środkami tego rodzaju będą produkty produkcji $\mathrm{nr} 2$, na przykład fortepiany, a także uboczne produkty produkcji nr 4, czyli dzieła. Do środków podmiotowych wypada zaliczyć:

- zadatki wrodzone,

- dyspozycje warsztatowe w zakresie twórczości artystycznej i naukowej,

- dyspozycje aksjologiczne.

Zadatki wrodzone $\mathrm{w}$ świetle intuicji właściwych marksizmowi nie są rozdzielone w sposób równy, niemniej prawie każda jednostka posiada jakieś zadatki wrodzone 
do zajmowania się takimi czy innymi dyscyplinami naukowymi bądź artystycznymi. Roli takich zadatków nie należy absolutyzować - ich brak może być zrekompensowany w procesie edukacji. Nie należy też sądzić, iż warunkiem podejmowania produkcji nr 4 jest posiadanie jakichś wyjątkowych zadatków wrodzonych. Zadatkami wrodzonymi - należy założyć - dysponują wszyscy ludzie w każdym ustroju społecznym.

Dyspozycje warsztatowe w zakresie twórczości artystycznej i naukowej nabywa się w specjalnym procesie edukacji - o zasadach dostępu jednostek do edukacji tego rodzaju decyduje ustrój społeczny.

Szczególne doniosłe znaczenie mają, jak sądzę, dyspozycje aksjologiczne - przekazywane zazwyczaj - bezwiednie - dzieciom przez rodziców. Chodzi o internalizację przez jednostkę systemu wartości wskazującego na twórczość artystyczną bądź naukową jako zasadniczą - najbardziej wartościową - formę samorealizacji indywidualnej.

\section{Implikacje teorii produkcji z Grundrisse dla teorii klas}

Produktami produkcji są nie tylko przedmioty i ludzie, ale zarazem stosunki między ludźmi, w pierwszej kolejności stosunki klasowe, które (najogólniej rzecz ujmując) polegają na tym, iż jedna klasa ma monopol na (pewne) środki produkcji, co stawia ją w pozycji uprzywilejowanej, a druga klasa ich nie posiada, co stawia ją w pozycji upośledzonej.

Pośrednia produkcja człowieka produkuje podział na klasy ekonomiczne: burżuazję i proletariat. Produkcja nr 3 produkuje podział na klasy reprodukcyjne: klasę obsługiwaną i klasę obsługującą. Produkcja nr 4 wytwarza podział na klasy kulturowe: inteligencję i nie-inteligencję.

Nie należy tego oczywiście rozumieć w ten sposób, iż pośrednia produkcja człowieka z natury rzeczy wytwarza podział na burżuazję i proletariat, produkcja $\mathrm{nr} 3$ z natury rzeczy wytwarza podział na obsługiwanych i obsługujących, a produkcja $\mathrm{nr} 4$ z natury rzeczy wytwarza podział na inteligencję i nie-inteligencję. Te same produkcje mogą bowiem - w odmiennych okolicznościach - wytwarzać stosunki bezklasowe (bądź innego rodzaju układy stosunków klasowych). Idzie raczej o to, iż każdy z wchodzących tu w grę podziałów klasowych musi być reprodukowany, a do oczywistych warunków reprodukcji każdego podziału klasowego należy trwanie odpowiedniej produkcji. Przerwanie produkcji nr 1 i 2 siłą rzeczy przerwałoby istnienie burżuazji i proletariatu itd.

Marksizm - trzymając się „zwykłej” teorii produkcji - definiuje klasy społeczne wyłącznie w odniesieniu do pośredniej produkcji człowieka, czyli sprowadza wielość podziałów klasowych do jednego tylko podziału na klasy ekonomiczne, w uproszczeniu: do podziału na burżuazję i proletariat - pozostawiając w cieniu podziały klasowe wytwarzane na gruncie innych rodzajów produkcji. Wyparte podziały klasowe 
zostają uwzględnione wtórnie - przez ich „wpisanie” w wyjściową strukturę klas ekonomicznych jako jej uszczegółowienie. Na przykład inteligencja może być ujmowana jako szczególna warstwa proletariatu wykonująca tak zwana pracę umysłową bądź też jako warstwa ideologów zajmująca się produkcją ideologii legitymizującej panowanie burżuazji (niekiedy: przechodząca na stronę proletariatu i produkująca ideologię delegitymizującą panowanie burżuazji). W pierwszym wypadku lokalizuje się ją we wnętrzu procesu pośredniej produkcji człowieka, w drugim przypad$\mathrm{ku}$ - ponad tym procesem, w jego nadbudowie. W pierwszym wypadku uznaje się ją za niezbędny warunek funkcjonowania procesu pośredniej produkcji człowieka (na określonym szczeblu rozwoju sił wytwórczych), w drugim - za niezbędny warunek jego funkcjonowania w burżuazyjnej formie społecznej. W pierwszym wypadku ewentualna dezercja inteligencji musiałaby doprowadzić do paraliżu procesu pośredniej produkcji człowieka, w drugim - dezercja tego rodzaju nie zaszkodziłaby procesowi pośredniej produkcji człowieka jako takiemu, natomiast uniemożliwiłaby jego kontynuację w burżuazyjnej formie społecznej. W obydwu wypadkach inteligencja definiowana jest bezpośrednio $\mathrm{w}$ odniesieniu do procesu pośredniej produkcji człowieka, a więc jako warstwa spełniająca jakąś funkcję wewnątrz tego procesu bądź w jego nadbudowie. Podejście to wydaje mi się jednak błędne. Sensowna definicja inteligencji wymaga odwołania się do tego procesu produkcji, na gruncie którego jest ona bezpośrednio wytwarzana (czyli produkcji $\mathrm{nr}$ 4), natomiast ewentualne funkcje spełniane przez członków inteligencji w odniesieniu do innych procesów produkcji, a więc w odniesieniu do innych podziałów klasowych, winny stanowić dopiero przedmiot empirycznego badania (nie zaś treść jej definicji). Inteligencję definiuje jej podmiotowo-przedmiotowy udział w produkcji $\mathrm{nr} 4$.

Zamiast „wpisywania” klas kulturowych i reprodukcyjnych w strukturę opartą na klasach ekonomicznych proponuję podejście zakładające współistnienie trzech odrębnych podziałów klasowych (reprodukowanych na gruncie odrębnych procesów produkcyjnych); podziałów logicznie od siebie niezależnych, co nie znaczy: nieoddziałujących na siebie. W społeczeństwie kapitalistycznym istnieją zatem trzy niepokrywające się ze sobą - klasy uprzywilejowane: burżuazja, klasa obsługiwana i inteligencja.

Przy założeniu, iż jedynym prawdziwie produkcyjnym procesem produkcji jest proces produkcji bogactwa rzeczywistego, czyli produkcja $\mathrm{nr} 4$, klasą najbardziej uprzywilejowaną jest inteligencja. Inteligencja jest klasą najbogatszą, a właściwie: jedyną klasą bogatą. Jest bowiem dysponentką bogactwa par excellence, czyli bogactwa podmiotowego. Ze względów objętościowych nie możemy przeprowadzić tu szczegółowej charakterystyki tej jedynej klasy współczesnych bogaczy. Ograniczę się zatem do uwagi, iż inteligencja składa się z dwóch części:

- inteligencji twórczej (tworzącej i konsumującej dzieła),

- inteligencji nietwórczej (konsumującej dzieła, ale ich nie wytwarzającej). 
Nie-inteligencję wyróżnia z kolei to, iż ani nie tworzy dzieł, ani ich nie konsumuje.

Niniejsze rozważania kończę refleksją, iż marksistowska teoria klas winna zostać przekształcona $\mathrm{z}$ teorii klas ekonomicznych w teorię współistnienia trzech odrębnych podziałów klasowych. Podział na klasę obsługującą i obsługiwaną od czasów Engelsa znajduje się w orbicie zainteresowania teorii marksistowskiej (jest on jednym z zasadniczych przedmiotów marksistowskiej refleksji nad patriarchatem). Pora uwzględnić podział na klasę prawdziwych bogaczy i klasę prawdziwych biedaków.

\section{THE THEORY OF PRODUCTION FROM GRUNDRISSE AND ITS IMPLICATIONS FOR MARXISM}

\section{Summary}

The article is an attempt to develop two of Marx's thoughts (appearing in Grundrisse):

- the final result of production is always a man,

- the real richness are developed creative forces of individuals.

Serious treatment of the above theses implies a thorough modification of the traditionally Marxist hierarchy of production processes. This has its consequences for class theory.

Keyword: Marxism, Grundrisse, production, free time, reproductive work, intelligence, social class, cultural class, capitalism, communism 